\title{
Differences in embryonic development in sensitive and resistant matings to pregnancy block stimuli in mice
}

\author{
H. J. Chung ${ }^{1}$, J. K. Pak ${ }^{1}$, B. K. Kim¹, Y. K. Lee ${ }^{1}$, S. K. Im¹, H. H. Seong ${ }^{1}$, S. J. Uhm²,

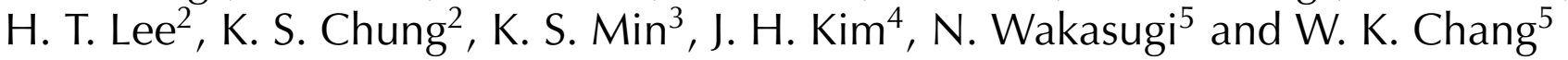 \\ ${ }^{1}$ Animal Biotechnology Division, National Livestock Research Institute, Rural Development \\ Administration, Suwon, Korea; ${ }^{2}$ Animal Resources Research Center, Konkuk University, Seoul, Korea; \\ ${ }^{3}$ Graduate School of Biotechnology, Hankyong National University, Ansung, Korea; ${ }^{4}$ Division of Applied \\ Life Science, College of Agriculture, Gyeonsang National University, JinJu, Korea; and ${ }^{5}$ School of \\ Bioagricultural Sciences, Nagoya University, Chikusa, Nagoya, Japan
}

Pregnancy block from exposure to foreign male mouse pheromones is sensitive to both male and female mating strain, as well as the foreign male pheromone-producing strain. Incidence of pregnancy block by male pheromones in mice is different depending on the combination of females, stud males and stimulus males. BALB/cA females mated with BALB/cA males showed a $100 \%$ pregnancy block when exposed to males of the DDK strain (Chung et al., 1997). In contrast, BALB/cA females mated with males of dissimilar strain show high rates of pregnancy even if they are exposed to DDK males; this difference is thought to be due to the difference in viability of embryos (Chung et al., 1999). The present study investigated how development of BALB/cA and F1 embryos differ under the influence of pregnancy block stimuli. F1 embryos had significantly higher numbers of cells than did the BALB/ cA embryos $(P<0.05)$ at day 3 of pregnancy after exposure to DDK males or after bromocriptine (dopamine agonist, $4 \mathrm{mg} \mathrm{kg}^{-1}$, i.p.) treatment. Histological observation after bromocriptine treatment revealed that: (i) on day 4 of pregnancy, BALB/cA embryos tended to form a large blastocoel, but showed abnormalities such as degeneration of primitive endoderm and depression of the outer trophoblastdistal endoderm layer at the periphery of the inner cell mass (ICM) or detachment of the ICM from the outer layer. In contrast, $60-70 \%$ of $\mathrm{F} 1$ embryos were normal late blastocysts and incipient egg cylinders, but $28-40 \%$ of early blastocysts were degenerating; and (ii) day 5 BALB/cA embryos were in the range from incipient egg cylinder with a large proamniotic cavity to ectoplacental cone only, but their proximal endoderm and trophoblast-distal endoderm layer were degenerating. In contrast, the F1 embryos were mostly at the egg cylinder stage and maintained normal structure except for occasional enlargement of the developing yolk sac cavity. These results indicate that the lining of the inner surface of trophoblast by distal endoderm layer may be more firmly established and that the inner environment for development of $F 1$ embryos may be more effectively maintained, thereby making them more resistant to deleterious influences due to pregnancy block stimuli than are BALB/cA embryos.

\section{Introduction}

Pregnancy block by male pheromones in mice has been investigated mainly with respect to the chemical nature of the male pheromones and neuroendocrinological mechanisms disturbing pregnancy. The male pheromones are thought to be a mixture of major urinary proteins (Peter, 2001) and volatile compounds such as 2-sec-butyl dihydrothiazole, dehydro-exo-brevicomin, farnesons and heptanones in the urine (Keveren, 1998). The pheromonal effect is mediated through the accessory part of the olfactory system (Keveren, 1978) and then

Email: hakjaena@rda.go.kr enhances activity of dopaminergic neurones (Keveren, 1982; Marchlewska-Koj, 1983), which in turn inhibits the prolactin surge necessary for development of corpora lutea. In effect, administration of dopamine agonist synchronized with prolactin surges also induces pregnancy block (Bellringer et al., 1980; Lomas and Keveren, 1982).

Pheromone production by male mice and sensitivity of female mice are both under genetic control. Males of the $\mathrm{C} 57 \mathrm{BL}$ strain are less effective in pheromonal action (Chipman and Bronson, 1968; Hoppe, 1975; Marchlewska-Koj, 1977). Eleftheriou et al. (1972, 1973) reported that pheromone production was controlled by a single gene. In addition, the major histocompatibility complex $(\mathrm{MHC})$ is involved in pregnancy block (Yamazaki et al., 1983, 1986; Singh, 2001). Chapman 
and Whitten (1969) demonstrated that the sensitivity of female mice was controlled by a single gene, and that female mice of the BALB/cDg and SJL/J strains are sensitive to the odour of alien males.

Chung et al. (1997, 1999) presented the possibility that embryonic viability is one of the factors involved in pregnancy block by male pheromones. BALB/CA females mated with BALB/CA males and exposed to DDK males showed a $100 \%$ pregnancy block, and the embryos destined to die under this condition show several abnormalities due to disturbance in trophoblast differentiation or its maintenance. In contrast, when the $\mathrm{BALB} / \mathrm{CA}$ females were mated with males of other strains such as $\mathrm{CBA} / \mathrm{J}, \mathrm{C} 3 \mathrm{H} / \mathrm{HeN}, \mathrm{C} 57 \mathrm{BL} / 6 \mathrm{Cr}$ and $\mathrm{IXBL}$, they were resistant to pregnancy block even when they were subsequently exposed to DDK males; it is likely that prevention of pregnancy block may be due to the viability of the F1 embryos. Furthermore, similar results were also observed in the pharmacological induction of pregnancy block. BALB/CA females mated with BALB/CA males showed complete pregnancy block when treated with the dopamine agonist. In contrast, BALB/cA females mated with alien males and treated in the same way showed significantly higher rates of pregnancy. These results indicate that embryonic genotypes must be taken into consideration in the investigation of pregnancy block.

The present study was undertaken to investigate how development of $\mathrm{F} 1$ embryos differs from that of BALB/CA embryos in the deteriorated tract of BALB/CA females exposed to the stimuli inducing pregnancy block, that is, exposure to DDK males or treatment with dopamine agonist.

\section{Materials and Methods}

\section{Animals}

The strains of mice used in the present study were $\mathrm{BALB} / \mathrm{CA}, \mathrm{CBA} / \mathrm{J}, \mathrm{C} 3 \mathrm{H} / \mathrm{HeN}, \mathrm{C} 57 \mathrm{BL} / 6 \mathrm{Cr}$, DDK and IXBL. All mice were purchased from an animal breeder (JungAng Laboratory Animal Co., Seoul). Production colonies were made and their descendants were used for experimentation. Some BALB/cA females were purchased from the above breeder at the age of 5-7 weeks and were used for experiments after 2-4 weeks of adaptation. Mice were kept under controlled conditions (approximately $23^{\circ} \mathrm{C} ; 12 \mathrm{~h}$ light: $12 \mathrm{~h}$ darkness; food and water available ad libitum). All animal procedures were performed according to the Guidelines for Animal Experimentation of the National Livestock Research Institute.

\section{Mating and exposure to stimulus males}

$\mathrm{BALB} / \mathrm{CA}$ females were mated with males of the $\mathrm{BALB} / \mathrm{CA}, \mathrm{CBA} / \mathrm{J}, \mathrm{C} 3 \mathrm{H} / \mathrm{HeN}, \mathrm{C} 57 \mathrm{BL} / 6 \mathrm{Cr}$ and IXBL strains at the age of 2.0-2.5 months and were checked once a day for a vaginal plug. In the morning on which the vaginal plug was found the females were removed from the stud males and exposed to either DDK males (hereafter, referred to as experimental females) or other males belonging to the same strain as stud males (hereafter, referred to as control females). Exposure cage and procedures were as described by Chung et al. (1999). The day on which the plug was found was designated day 0 of pregnancy.

\section{Injection of dopamine agonist}

$\mathrm{BALB} / \mathrm{CA}$ females mated with stud males were given i.p. injections of dopamine agonist (bromocriptine methanesulphonate; RBI Research Biochemical Co., L. P. Natick, MA) at the times of the nocturnal and diurnal surges (06:00 $\mathrm{h}$ and 21:00 $\mathrm{h}$ on day 1 of pregnancy: Barkley et al., 1978; Rosser et al., 1989) at the dose of $4 \mathrm{mg} \mathrm{kg}^{-1}$ body weight in each injection.

\section{Counting of number of cells of embryos}

Embryos were collected at 14:00 h on day 3 of pregnancy from BALB/CA females mated with stud males and exposed to stimulus males, or treated with bromocriptine on day 1 of pregnancy. Embryos were flushed from the uterus with M16 medium (Hogan et al.,

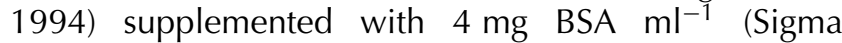
Chemical Co., St Louis, MO) and classified into morulae or blastocysts. The number of cells in each embryo was counted by the method of Tarkowski (1966). Morulae and blastocysts were treated with hypotonic solution $(0.5 \%(\mathrm{w} / \mathrm{v})$ sodium citrate solution) for $15 \mathrm{~min}$ at room temperature $\left(22 \pm 3^{\circ} \mathrm{C}\right)$ and placed on grease-free slides in a minimum volume of hypotonic solution. Fixative (ethanol:glacial acetic acid, 3:1) was applied drop by drop under a dissecting microscope (Nikon, Tokyo). The slides were air dried and stained with $1 \%(\mathrm{w} / \mathrm{v})$ aceticlactic orcein (Katayama Chemical Co., Osaka) solution. The number of nuclei was taken as the number of cells in an embryo.

\section{Histological observation of embryos at days 4 and 5 of pregnancy}

Uterine horns were dissected out at days 4 and 5 of pregnancy from BALB/CA females mated with stud males and treated with bromocriptine as described above (treated group) or given no treatment (control group), fixed in Bouin's solution (Sigma Chemical Co.) for $24 \mathrm{~h}$ and transferred to $70 \%(\mathrm{v} / \mathrm{v})$ ethanol. Uterine tissues were dehydrated by graded alcohol series and embedded in paraffin wax. Serial sections were cut (6 $\mu \mathrm{m}$ thickness) and stained with haematoxylin (Sigma Chemical Co.) and eosin B (Sigma Chemical Co.). Photomicrographs were 
(a)
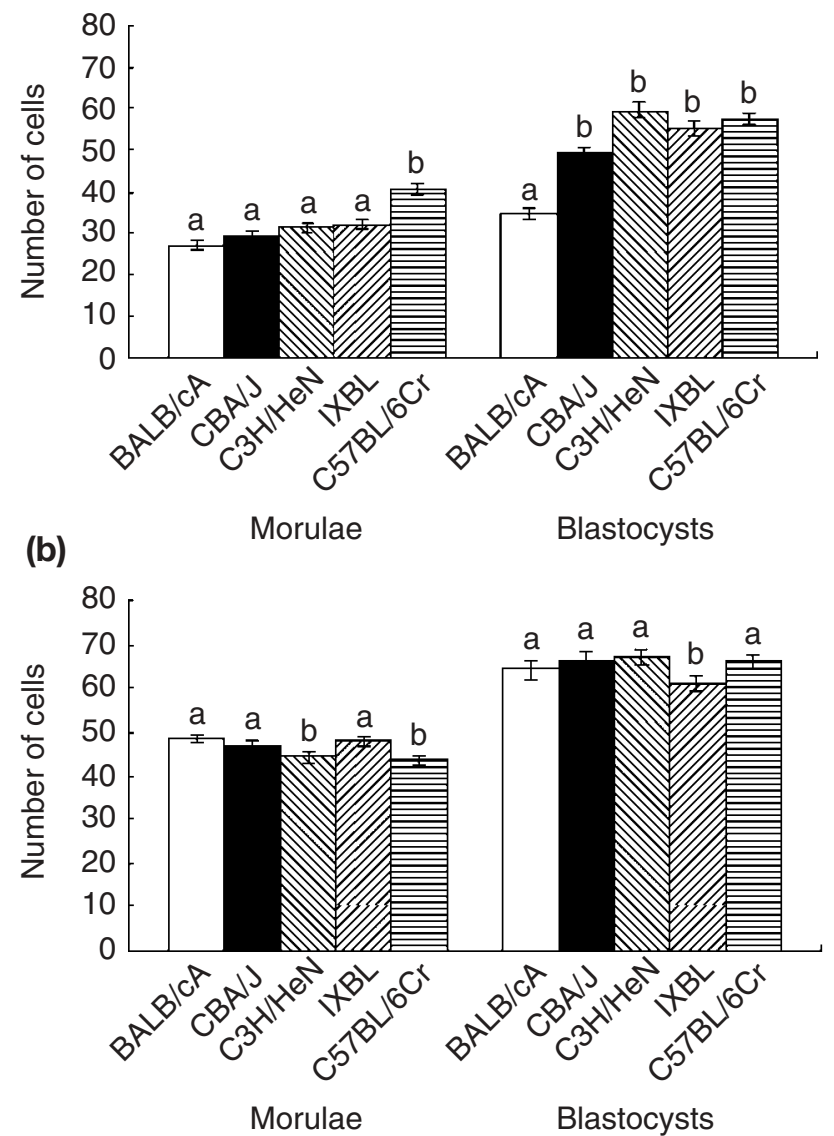

Fig. 1. Number of cells of mouse embryos at day 3 of pregnancy from $B A L B / C A$ females mated with males of five strains (BALB/CA

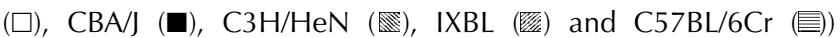
and exposed to (a) DDK males (experimental groups) or (b) other males belonging to the same strain as stud males (control groups). Morulae and blastocysts were examined separately.

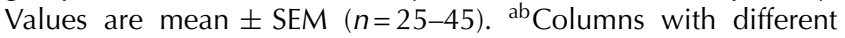
superscripts differ significantly within each group $(P<0.05$, twoway ANOVA test). For the comparison between the experimental and control groups, the difference between numbers of cells in the morulae is significant $(P<0.05$, two-way ANOVA test) except for the mating $\mathrm{BALB} / \mathrm{CA}$ females $\times \mathrm{BALB} / \mathrm{CA}$ males versus $\mathrm{BALB} / \mathrm{CA}$ females $\times$ C57BL/6Cr males $(P<0.05$, two-way ANOVA test). The data for the four BALB/CA groups are taken from Chung et al. (1997).

taken using a Nikon upright light microscope at $\times 400$ magnification.

\section{Statistical analysis}

Statistical significance for difference among means was analysed by parametric two-way ANOVA, Duncan's new multiple range test or chi-squared test. Values are mean \pm SEM. Differences were considered to be significant at $P<0.05$.

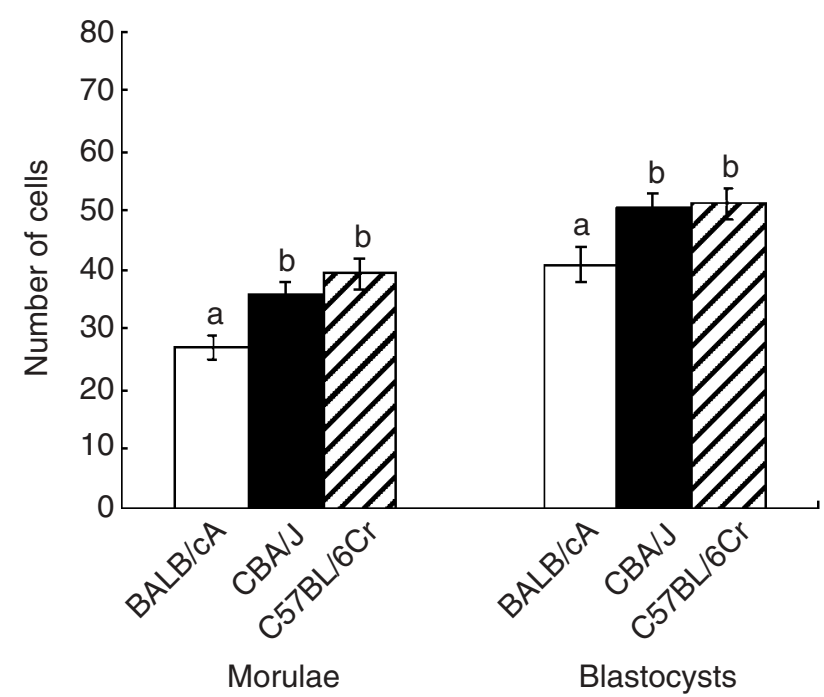

Fig. 2. Number of cells of mouse embryos from BALB/cA females mated with males of three strains (BALB/CA ( $\square), \mathrm{CBA} / \mathbf{J}(\mathbf{\square})$ and $\mathrm{C} 57 \mathrm{BL} / 6 \mathrm{Cr}(\square))$ that were given bromocriptine $\left(4 \mathrm{mg} \mathrm{kg}^{-1}\right.$ body weight, i.p.) on day 1 of pregnancy and killed at 14:00 h on day 3 of pregnancy. Values are mean \pm SEM $(n=18-21$ (morulae) or 2329 (blastocysts)). ${ }^{a b}$ Different letters indicate significant differences within morulae or blastocysts $(P<0.05$, two-way ANOVA test).

\section{Results}

\section{Number of cells in embryos at day 3 of pregnancy}

The number of cells in embryos at day 3 of pregnancy is shown (Fig. 1). Morulae and blastocysts from the experimental females (BALB/CA females mated with BALB/CA males and exposed to DDK males) had fewer cells than did those from the control females (BALB/CA females mated with BALB/CA males and exposed to males of the same strain as stud): $27.0 \pm 1.2$ versus $48.6 \pm 1.0$ for morulae, and $34.8 \pm 1.4$ versus $64.1 \pm 2.0$ for blastocysts (both $P<0.05$, two-way ANOVA). Experimental embryos also had fewer cells than did control embryos after mating of BALB/CA females with CBA/J males: $29.3 \pm 1.1$ versus $46.8 \pm 1.2$ for morulae and $49.4 \pm 1.0$ versus $66.3 \pm 2.1$ for blastocysts (both $P<0.05$ ). In the mating of BALB/cA females with $\mathrm{C} 3 \mathrm{H} / \mathrm{HeN}$ males, a significant difference in the number of cells was observed for morulae (31.4 \pm 1.2 (experimental) versus $44.2 \pm 1.3$ (control; $P<0.05$ )) but not for blastocysts $(59.4 \pm 2.0$ (experimental) versus $67.1 \pm 1.9$ (control; $P<0.05)$ ). Similar results were observed in the mating of BALB/CA females with IXBL males; that is, a significant difference was observed for the number of cells in morulae $(32.1 \pm 1.0$ (experimental) versus $47.9 \pm 1.0$ (control; $P<0.05)$ ) but not in the blastocysts $(55.0 \pm 1.7$ (experimental) versus $61.2 \pm 1.8$ (control; $P<0.05)$ ). In contrast, in embryos resulting from the mating of BALB/CA females with $\mathrm{C} 57 \mathrm{BL} / 6 \mathrm{Cr}$ males, the number of cells was not significantly different between 

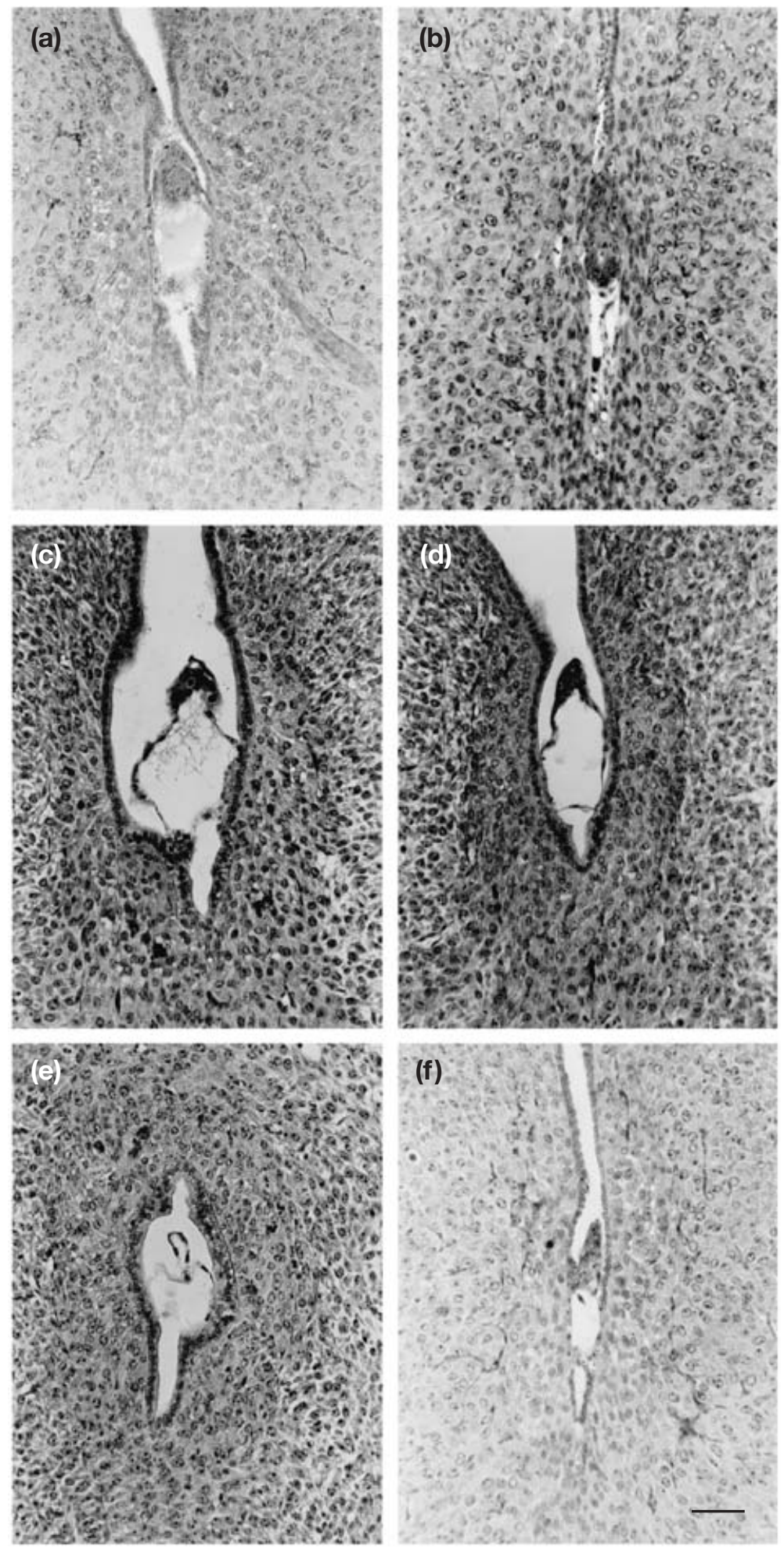

Fig. 3. Light micrographs of mouse embryos at day 4 of pregnancy from $\mathrm{BALB} / \mathrm{CA}$ females mated with $\mathrm{BALB} / \mathrm{CA}, \mathrm{CBA} / \mathrm{J}, \mathrm{C} 3 \mathrm{H} / \mathrm{HeN}$ or $\mathrm{C} 57 \mathrm{BL} / 6 \mathrm{Cr}$ males and treated with dopamine agonist (bromocriptine, $4 \mathrm{mg} \mathrm{kg}^{-1}$ body weight, i.p) on day 1 of pregnancy. (a,c,e) BALB/cA embryos and (b,d,f) $F_{1}$ embryos. (a) Late blastocyst with round inner cell mass (ICM). Both trophoblast and ICM are degenerate. (b) Incipient egg cylinder with a small proamniotic cavity (BALB/ cA female $\times$ C57BL/6Cr male). Note narrow yolk sac cavity. (c) Blastocyst with 
Table 1. Developmental stages of mouse embryos at days 4 and 5 of pregnancy observed in BALB/CA females mated with BALB/CA, $\mathrm{CBA} / \mathrm{J}, \mathrm{C} 3 \mathrm{H} / \mathrm{HeN}$ or $\mathrm{C} 57 \mathrm{BL} / 6 \mathrm{Cr}$ males and treated with bromocriptine $\left(4 \mathrm{mg} \mathrm{kg}^{-1}\right.$ body weight, i.p) on day 1 of pregnancy (treated) or given no treatment (control)

\begin{tabular}{|c|c|c|c|c|c|c|c|c|c|}
\hline \multirow{3}{*}{$\begin{array}{l}\text { Day of } \\
\text { observation }\end{array}$} & \multirow[b]{3}{*}{ Embryonic status } & \multicolumn{8}{|c|}{ Number of embryos } \\
\hline & & \multicolumn{2}{|c|}{$\mathrm{BALB} / \mathrm{cA} \times \mathrm{BALB} / \mathrm{cA}$} & \multicolumn{2}{|c|}{$\mathrm{BALB} / \mathrm{cA} \times \mathrm{CBA} / \mathrm{J}$} & \multicolumn{2}{|c|}{$\mathrm{BALB} / \mathrm{cA} \times \mathrm{C} 3 \mathrm{H} / \mathrm{HeN}$} & \multicolumn{2}{|c|}{$\mathrm{BALB} / \mathrm{CA} \times \mathrm{C} 57 \mathrm{BL} / 6 \mathrm{Cr}$} \\
\hline & & Treated & Control & Treated & Control & Treated & Control & Treated & Control \\
\hline \multirow[t]{5}{*}{ Day 4} & Incipient egg cylinder & 0 & 3 & 8 & 4 & 6 & 4 & 7 & 4 \\
\hline & Late blastocyst with round ICM & 14 & 13 & 2 & 7 & 7 & 10 & 6 & 9 \\
\hline & Late blastocyst with thin ICM & 9 & 16 & 10 & 16 & 15 & 20 & 11 & 24 \\
\hline & $\begin{array}{l}\text { Degenerating late blastocyst } \\
\text { without ICM }\end{array}$ & 17 & 0 & 0 & 0 & 0 & 0 & 0 & 0 \\
\hline & Degenerating early blastocyst & 0 & 2 & 13 & 5 & 11 & 4 & 11 & 2 \\
\hline Total & & $40(4)$ & $34(3)$ & $33(3)$ & $32(3)$ & $39(4)$ & $37(4)$ & $34(3)$ & $39(4)$ \\
\hline \multirow[t]{7}{*}{ Day 5} & $\begin{array}{l}\text { Egg cylinder with a large } \\
\text { proamniotic cavity }\end{array}$ & 9 & 7 & 5 & 7 & 11 & 4 & 6 & 7 \\
\hline & $\begin{array}{l}\text { Early egg cylinder with one or } \\
\text { two small cavities }\end{array}$ & 3 & 12 & 5 & 11 & 6 & 16 & 7 & 13 \\
\hline & Incipient egg cylinder & 6 & 1 & 3 & 1 & 1 & & 3 & 2 \\
\hline & $\begin{array}{l}\text { Disorganized embryonic mass } \\
\text { surrounded by decidua }\end{array}$ & 4 & 2 & 4 & 3 & 5 & 1 & 3 & 2 \\
\hline & Ectoplacental cone only & 2 & 0 & 1 & 0 & 0 & 0 & 1 & 0 \\
\hline & Proliferated decidua with & 16 & 0 & 0 & 0 & 0 & 0 & 0 & 0 \\
\hline & no embryonic cells & 16 & 0 & 0 & 0 & 0 & 0 & 0 & 0 \\
\hline Total & & $40(4)$ & $22(2)$ & $18(3)$ & $22(2)$ & $23(4)$ & $21(2)$ & $20(3)$ & $24(2)$ \\
\hline
\end{tabular}

ICM: inner cell mass.

Numbers in parentheses indicate the number of female mice examined.

experimental $(40.7 \pm 1.2)$ and control $(43.6 \pm 1.0)$ morulae, but there was a significant difference between experimental $(57.4 \pm 1.30)$ and control $(66.0 \pm 1.7$; $P<0.05)$ blastocysts.

These results indicate that there is a strong suppression of increase in cell number in BALB/CA and (BALB/CA females $\times$ CBA/J males) $F 1$ embryos at both the morula and blastocyst stages, whereas (BALB/cA females $\times \mathrm{C} 3 \mathrm{H} /$ $\mathrm{HeN}$ males) $\mathrm{F} 1$ and (BALB/CA females $\times$ IXBL males) F1 embryos show suppression at the blastocyst stage only.

The number of cells of embryos collected at day 3 of pregnancy from the BALB/CA females treated with bromocriptine $\left(4 \mathrm{mg} \mathrm{kg}^{-1}\right.$, i.p.) on day 1 of pregnancy is shown (Fig. 2). The BALB/CA embryos had significantly fewer cells $(P<0.05)$ than did the $\mathrm{F} 1$ embryos (BALB/CA females $\times \mathrm{CBA} / \mathrm{J}$ males or $\mathrm{C} 57 \mathrm{BL} / 6 \mathrm{Cr}$ males). The difference was significant in both morulae $(27.0 \pm 2.0$ versus $36.0 \pm 2.1$ or $39.3 \pm 2.4 ; P<0.05)$ and blastocysts $(41.0 \pm 2.3$ versus $50.3 \pm 3.0$ or $51.0 \pm 2.6 ; P<0.05)$. These results are similar to those observed in the exposure experiment to DDK males (Fig. 1a). When the embryos at the same stage in these two types of experiments were compared with each other (Fig. 1a versus Fig. 2), a significant difference was seen only in the morulae from the mating of $\mathrm{BALB} / \mathrm{CA}$ females $\times \mathrm{CBA} / \mathrm{J}$ males $(29.3 \pm 1.1$ versus $36.0 \pm 2.1 ; P<0.05$, Duncan's new multiple range test).

\section{Histological observation of embryos at days 4 and 5 of pregnancy}

Histological examination was performed on day 4 and day 5 embryos developing in the BALB/cA females mated with $\mathrm{BALB} / \mathrm{CA}, \mathrm{CBA} / \mathrm{J}, \mathrm{C} 3 \mathrm{H} / \mathrm{HeN}$ or $\mathrm{C} 57 \mathrm{BL} / 6 \mathrm{Cr}$ males and treated with bromocriptine on day 1 of pregnancy (treated group), or given no treatment (control group). The results are summarized (Table 1 ) and some examples are also shown (Figs 3 and 4). Of 40 BALB/cA embryos at day 4 in the treated group, 23 were late blastocysts with a round inner cell mass (ICM) or thin ICM, but they were mostly abnormal, showing degeneration of the proximal endoderm and the trophoblast-distal endoderm

degenerating ICM. Trophoblast-distal endoderm layer is pushed down at the periphery of ICM. (d) Blastocyst with thin ICM (BALB/CA female $\times \mathrm{C} 3 \mathrm{H} / \mathrm{HeN}$ male). This embryo looks normal as a whole except for a somewhat abnormal trophoblast-distal endoderm layer. (e) Degenerating late blastocyst without ICM. Note irregularly waved trophoblast and absence of ICM. (f) Degenerating early blastocyst (BALB/cA female $\times$ CBA/J male). Note poor development of trophoblast and a narrow blastocoel. Scale bar represents $45 \mu \mathrm{m}$. 

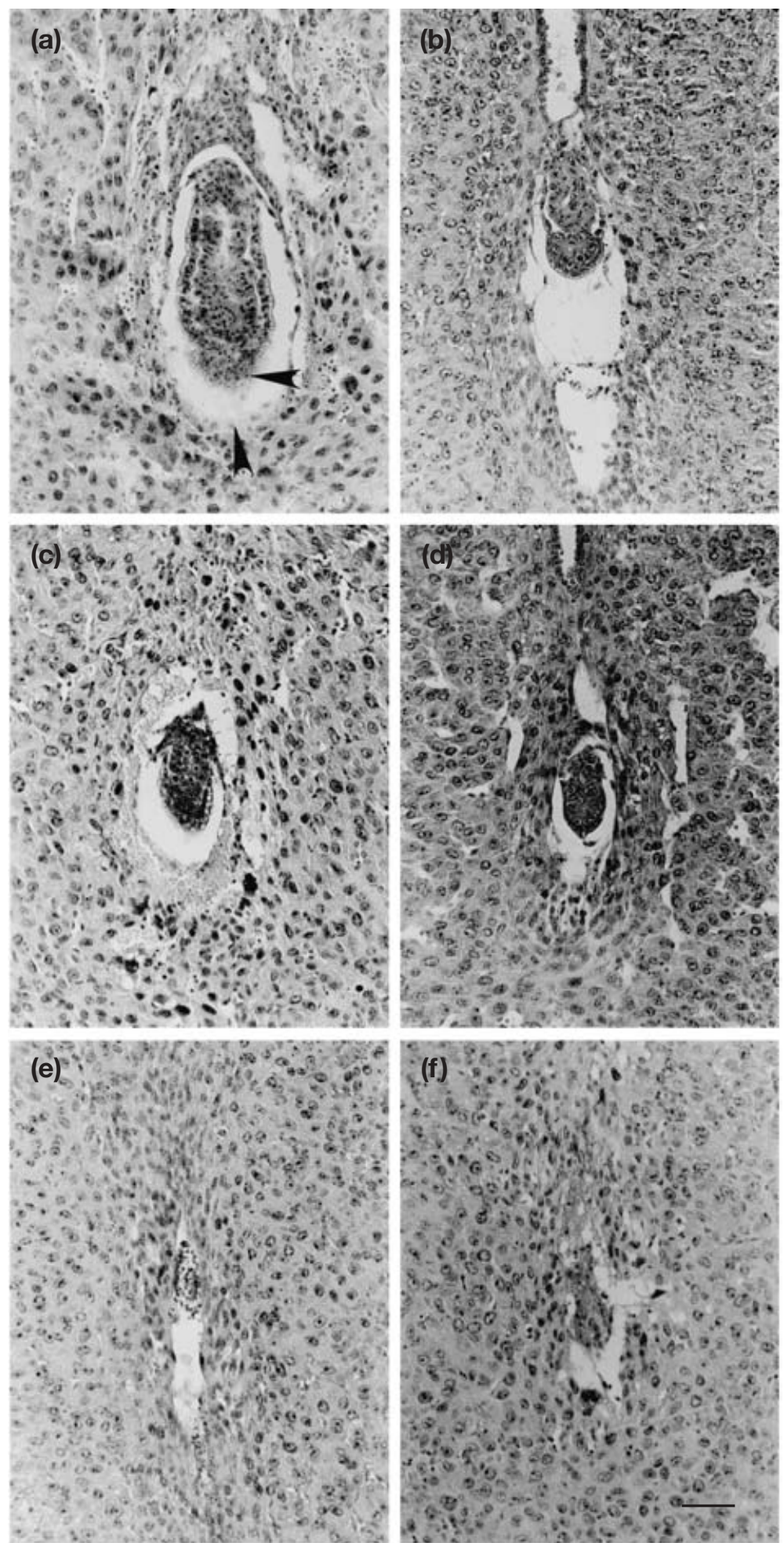

Fig. 4. Light micrographs of mouse embryos at day 5 of pregnancy from $\mathrm{BALB} / \mathrm{cA}$ females mated with $\mathrm{BALB} / \mathrm{cA}, \mathrm{C} 3 \mathrm{H} / \mathrm{HeN}$ or $\mathrm{C} 57 \mathrm{BL} / 6 \mathrm{Cr}$ males treated with dopamine agonist (bromocriptine, $4 \mathrm{mg} \mathrm{kg}^{-1}$ body weight, i.p) on day 1 of pregnancy. (a,c,e) BALB/cA embryos and (b,d,f) $F_{1}$ embryos. (a) Egg cylinder with a large proamniotic cavity. Note that the outer trophoblast-distal endoderm layer and proximal endoderm at ventral side are collapsing (arrowheads). (b) Egg cylinder with a small cavity $(\mathrm{BALB} / \mathrm{CA}$ female $\times \mathrm{C} 3 \mathrm{H} / \mathrm{HeN}$ male). Note enlarged 
layer (Fig. 3a). Some embryos showed depression at the periphery of the ICM (Fig. 3c); in this embryo, the ICM appears to be detaching from the trophoblastdistal endoderm layer. The other 17 embryos were degenerating late blastocysts without an ICM (Fig. 3e). Of 34 BALB/CA embryos in the control group, three were normal incipient egg cylinders, and 29 were normal late blastocysts. Only two embryos were degenerating early blastocysts with a small blastocoel. F1 embryos in the treated and control groups were at various stages of development: incipient egg cylinder (Fig. 3b), late blastocyst (Fig. 3d) and early blastocyst (Fig. 3f). All early blastocysts were degenerating, and they were observed more frequently in the treated groups than in the control groups. The difference in their incidence in treated and control groups was significant in the matings of $\mathrm{BALB} / \mathrm{CA} \times \mathrm{CBA} / \mathrm{J}(\mathrm{P}<0.05$, chi-squared test $)$ and $\mathrm{BALB} / \mathrm{CA} \times \mathrm{C} 57 \mathrm{BL} / 6 \mathrm{Cr}(\mathrm{P}<0.01)$ mice, but not in the $\mathrm{BALB} / \mathrm{CA} \times \mathrm{C} 3 \mathrm{H} / \mathrm{HeN}$ mating. The incipient egg cylinders mostly had a smaller yolk sac cavity in the F1 embryos compared with BALB/CA embryos, and the late blastocysts had a somewhat irregular trophoblastdistal endoderm layer in the treated groups compared with the control groups. When BALB/CA and F1 embryos of the treated groups were compared with each other, BALB/cA embryos tended to form a large blastocoel, but the outer trophoblast-distal endoderm layer appeared to be subject to degenerative change. In contrast, F1 embryos showed a tendency to form a smaller blastocoel, but the outer layer appeared to be more resistant to degenerative change.

At day 5 of pregnancy, 18 of 40 BALB/cA embryos in the treated group were at the incipient egg cylinder stage to egg cylinder with a large proamniotic cavity stage, but they mostly showed degenerative change in the proximal endoderm and trophoblast-distal endoderm layer (Fig. 4a,c). Four abnormalities were disorganized embryonic masses surrounded by decidua. Two abnormalities were implantation sites with ectoplacental cone only and 16 abnormalities were proliferated decidua with no embryonic cells (Fig. 4e). Of 22 control BALB/cA embryos at day 5 of pregnancy, seven were early egg cylinders with a large proamniotic cavity and 12 were early egg cylinders with one or two small cavities. The control embryos were all normal, but one was an irregular incipient egg cylinder and two were disorganized embryonic masses.

F1 embryos of treated groups were mostly at the egg cylinder with a large proamniotic cavity or early egg cylinder with one or two small cavity stages. The embryos were mostly normal, but some embryos showed irregularity of the trophoblast-distal endoderm layer (Fig. 4b). The incipient egg cylinders generally maintained normal organization (Fig. 4d). In contrast to the BALB/CA embryos, disintegration of proximal endoderm and the trophoblast-distal endoderm layer were less severe in the F1 embryos, and the yolk sac cavity was smaller. Some abnormalities were degenerated embryos with disorganized embryonic masses (Fig. 4f). Control F1 embryos were mostly at the stages of egg cylinder with a large proamniotic cavity or early egg cylinder with one or two small cavities, and they were all normal.

These results indicate that BALB/CA embryos show more severe degeneration in the proximal endoderm and trophoblast-distal endoderm layer compared with F1 embryos under the deteriorated uterine condition caused by bromocriptine treatment.

\section{Discussion}

Embryological investigations in the present and previous (Chung et al., 1997) studies have revealed several differences in embryonic development under the deteriorated condition due to pregnancy block stimuli between BALB/CA embryos and F1 (BALB/CA female $x$ alien male) embryos. BALB/CA embryos at day 3 of pregnancy had significantly fewer cells than did F1 embryos after exposure to DDK males or bromocriptine treatment. BALB/CA embryos at day 4 of pregnancy tended to form a large blastocoel, but this large blastocoel may possibly be due to weakening or degenerative change in the outer trophoblast-distal endoderm layer. In contrast, the F1 embryos tended to form a smaller blastocoel, but the outer trophoblast-distal endoderm layer was more resistant to degenerative change. BALB/CA embryos at day 5 of pregnancy were characterized by degeneration of proximal endoderm and the outer trophoblastdistal endoderm layer. In contrast, the F1 embryos that developed beyond the early egg cylinder stage mostly maintained normal embryonic structure except for occasional enlargement of the yolk sac cavity accompanied by a partial irregular trophoblast-distal endoderm layer. These results indicate that the outer trophoblastdistal endoderm layer is apt to degenerate in BALB/CA embryos when their environment for development is deteriorated; this degeneration may be due to weakening of trophoblast or distal endoderm or both.

yolk sac cavity due to degeneration of outer trophoblast-distal endoderm layer at the ventral side. (c) Incipient egg cylinder with no cavity. Note that the outer trophoblast-distal endoderm layer at ventral side and proximal endoderm show degenerative change and there is a large yolk sac cavity which may have resulted from weakening of the trophoblast-distal endoderm layer. (d) Incipient egg cylinder with no cavity (BALB/cA female $\times$ C57BL/6Cr males). (e) Prolifeated decidua with no embryonic cells at implantation site. (f) Prolifeated decidua with disorganized mass of embryonic cells (BALB/cA female $\times \mathrm{C} 3 \mathrm{H} / \mathrm{HeN}$ male). Scale bar represents $45 \mu \mathrm{m}$. 
Severe reduction in the number of cells in experimental BALB/CA embryos at day 3 of pregnancy may cause retardation of ICM development and its differentiation into embryonic ectoderm and endoderm. Thus, it is possible that the development of the ICM in BALB/CA embryos may be disturbed more strongly by the change in uterine environment caused by pregnancy block stimuli, which may lead to the imperfect differentiation of embryonic ectoderm and endoderm. Hence, the lining of the inner surface of the trophoblast by the distal endoderm may occur abnormally, which may cause a defective outer trophoblast-distal endoderm layer. The findings mentioned above indicate that development of trophoblast-distal endoderm might be superior in F1 embryos compared with BALB/CA embryos, but the lining of inner surface of trophoblast by distal endoderm might be less effective and formation of trophoblast-Reichert's membrane-distal endoderm layer may be imperfect in BALB/CA embryos. In addition, the outer layer undergoes degeneration as a first step. Accordingly, the inner environment for embryonic development cannot be maintained and degeneration of both proximal endoderm and embryonic or extraembryonic ectoderm follows. In F1 embryos, lining of the inner surface of trophoblast may be more complete and the inner environment for embryonic development can be maintained more effectively. Reichert's membrane forms between the trophoblast and distal endoderm; this membrane is thought to function as a filter performing selective passage of nutritional substances for embryos and a protective barrier to maintain inner environment for embryonic development. The strain combinations and experimental procedures of the present study may be a good experimental system in which to investigate the mechanisms controlling formation of Reichert's membrane and the underlying genetic factors.

Vulnerability of BALB/CA embryos to the deteriorated condition may be due to their stronger dependence on some of the uterine factors that stimulate embryonic development such as growth factors. The deficiency of such factors may cause depression of metabolic activity of BALB/CA embryos and result in disturbance of their development, as some growth factors are known to have stimulatory effects on the development of preimplantation embryos and their differentiation (Paria and Dey, 1990; Adamson, 1993; Harvey et al., 1995; Brison and Schultz, 1997, 1998; Kate, 1997). Moreover, it has been demonstrated that both insulin-like growth factor II (IGF-II) and insulin of maternal origin stimulate growth of mouse preimplantation embryos (Harvey and Kaye, 1990; Rappolee et al., 1992).

The metabolic activity of early embryos is also different depending on their genotype (Surani et al., 1990). The strong viability of the F1 embryos compared with BALB/CA embryos in the present study is due to the activities of paternally derived genes. Preimplantation development is influenced by $\mathrm{H}$-2-associated genes, with slow development associated with the $\mathrm{k}$ and $\mathrm{r}$ haplotypes (Goldbard and Warner, 1982; Goldbard et al., 1982). Glt may be interesting to investigate the genetic factors enhancing the viability of F1 embryos and how they express their effects, for example, how many loci are involved, or whether the activities of whole embryos are enhanced or whether the effects are expressed through extraembryonic tissues. Reduction in the number of cells in the four types of F1 embryo at day 3 of pregnancy showed different tendencies and, hence, there appear to be various genetic factors enhancing the viability of embryos. Paternal genome contributes to development of extraembryonic tissues (Barton et al., 1984; Surani, 1985). It would be interesting to investigate what types of gene make the F1 embryos more vigorous and how these genes act.

Synchronization of embryonic development and uterine receptivity is critical for successful implantation. The present and previous (Chung et al., 1999) studies indicate that viability of embryos may be one of the factors directing the physiological conditions leading to establishment of pregnancy. Embryonic oestrogen can stimulate development of corpora lutea in pigs (Flint et al., 1983). Cell adhesion molecules connecting blastocysts and uterine epithelium or invasive activity of trophoblast into the stroma may be other factors involved (Aplin, 1998). A recent report also indicates that preimplantation embryos may send a signal to endometrial epithelium and stroma, and enhance the receptivity of the uterus (Wakuda et al., 1999). It would be interesting to investigate how the signals from the embryos are sent to the ovary and how they stimulate development of corpora lutea. The experimental system of the present study may be useful as a tool for future investigations in this direction.

The authors thank J. Hyek Choi, J. Hyun Woo and Y. Yeon Lee (National Livestock Research Institute, Korea) for editing the manuscript and Y. Min Chang for critical suggestions. This work was supported in part by the National Livestock Research Institute (RDA, LS 0111). This project was supported by the Rural Development Administration (RDA).

\section{References}

Adamson ED (1993) Activities of growth factors in preimplantation embryos Journal of Cell Biochemistry 53 280-287

Aplin JD (1998) Adhesion molecules in implantation Reviews of Reproduction 2 84-93

Barkley MS, Bradford GE and Geschwind II (1978) The pattern of plasma prolactin concentration during the first half of mouse gestation Biology of Reproduction 19 291-296

Barton SC, Surani MAH and Norris ML (1984) Role of paternal and maternal genomes in mouse development Nature 311 374-376

Bellringer JF, Pratt HPM and Keveren EB (1980) Involvement of the vomeronasal organ and prolactin in pheromonal induction of delayed implantation in mice Journal of Reproduction and Fertility 59 223-228

Brison DR and Schultz RM (1997) Apoptosis during mouse blastocyst formation: evidence for a role for survival factors including TGF- $\alpha$ Biology of Reproduction 56 1088-1096 
Brison DR and Schultz RM (1998) Increased incidence of apoptosis in transforming growth factor $\alpha$ deficient mouse blastocyst Biology of Reproduction 59 136-144

Chapman VM and Whitten WK (1969) The occurrence and inheritance of pregnancy block in inbred mice Genetics 61-2 (Supplement 9)

Chipman PK and Bronson FH (1968) Pregnancy blocking capacity and inbreeding in laboratory mice Experientia 24 199-200

Chung HJ, Reyes ABV, Watanabe K, Tomogane H and Wakasugi N (1997) Embryonic abnormality caused by male pheromonal effect in pregnancy block in mice Biology of Reproduction 57 312-319

Chung HJ, Zhao WD and Wakasugi N (1999) Participation of embryonic genotype in the pregnancy block phenomenon in mice Biology of Reproduction 61 367-371

Eleftheriou BE, Bailey DW and Zarrow MX (1972) A gene controlling male pheromonal facilitation of PMSG-induced ovulation in mice Journal of Reproduction and Fertility 31 155-158

Eleftheriou BE, Christenson CM and Zarrow MX (1973) The influence of exteroceptive stimuli and pheromonal facilitation of ovulation in different strains of mice Journal of Endocrinology 57 363-370

Flint APF, Burton RD, Gadsby JE, Heap RB and Sheldrick EL (1983) Embryonic steroid synthesis and luteal oxytocin production: controlling mechanisms for the maternal recognition of pregnancy Journal of Steroid Biochemistry 19 973-978

Goldbard SB and Warner CM (1982) Genes affect the timing of early mouse development Biology of Reproduction 27 419-424

Goldbard SB, Verbanac KK and Warner CM (1982) Role of the H-2 complex in preimplantation mouse embryo development Biology of Reproduction 26 591-596

Harvey MB and Kaye PL (1990) Insulin increases the cell number of the inner cell mass and stimulates morphological development of mouse blastocysts in vitro. Development 110 963-967

Harvey MB, Leco KJ, Arcellana-Panlilio MY, Zhang X, Edward DR and Schultz GA (1995) Role of growth factors during peri-implantation development Molecular Human Reproduction 3 712-718

Hogan B, Costantini F, Beddington R and Lacy E (1994) Manipulating the Mouse Embryo: A Laboratory Manual Cold Spring Harbor Laboratory Press, New York

Hoppe PC (1975) Genetic and endocrine studies of the pregnancy-blocking pheromone of mice Journal of Reproduction and Fertility 45 109-115

Kate H (1997) Cell death in the mammalian blastocyst Molecular Human Reproduction 3 919-925

Keveren EB (1978) Olfaction and taste - dual systems for sensory processing Trends in Neuroscience $132-34$

Keveren EB (1982) The accessory olfactory system and its role in pheromonally mediated changes in prolactin. In The Olfaction and Endocrine Regulation pp 127-140 Ed. W Breiphol. IRL Press, London

Keveren EB (1998) Vomeronasal/accessory olfactory system and pheromonal recognition Chemical Senses 23 491-494
Lomas DE and Keveren EB (1982) Role of the vomeronasal organ and prolactin in the acceleration of puberty in female mice Journal of Reproduction and Fertility 66 101-107

Marchlewska-Koj A (1977) Pregnancy block elicited by urinary proteins of male mice Biology of Reproduction 17 729-732

Marchlewska-Koj A (1983) Pregnancy blocking by pheromones. In Pheromones and Reproduction in Mammals pp 113-174 Ed. JG Vandenbergh. Academic Press, New York

Paria BC and Dey SK (1990) Preimplantation embryo development in vitro: cooperative interactions among embryos and role of growth factors Proceedings National Academy of Sciences USA 87 4756-4760

Peter B (2001) How mice make their mark Nature 414 590-591

Rappolee DA, Sturm KS, Behrendtsen O, Schultz GA, Pedersen RA and Werb Z (1992) Insulin-like growth factor II acts through an endogenous growth pathway regulated by imprinting in early mouse embryo Genes and Development 6 939-952

Rosser AE, Remfry CJ and Keverne EB (1989) Restricted exposure of mice to primer pheromones coincident with prolactin surges block pregnancy by changing hypothalamic dopamine release Journal of Reproduction and Fertility 87 553-559

Singh PB (2001) Chemosensation and genetic individuality Reproduction 121 529-539

Surani MAH (1985) Development of reconstituted mouse eggs and embryos provides genetic models for fetal development in the human. In Implantation of the Human Embryo pp 179-186 Eds RG Edwards et al. Academic Press, New York

Surani MAH, Kothary R, Allen ND, Singh PB, Fundele R, Ferguson-Smith AC and Barton SC (1990) Genome imprinting and development in the mouse Development Supplement 89-98

Tarkowski AK (1966) An air-drying method for chromosome preparations from mouse eggs Cytogenetics 5 394-400

Wakuda K, Tanakura K, Nakanishi K, Kita N, Shi H, Hirose M and Noda Y (1999) Embryo-dependent induction of embryo receptivity in the mouse endometrium Journal of Reproduction and Fertility 115 315-324

Yamazaki K, Beauchamp GK, Wysocki CJ, Bard J, Thomas L and Boyse EA (1983) Recognition of $\mathrm{H}-2$ types in relation to the blocking of pregnancy in mice Science 221 186-188

Yamazaki K, Beauchamp GK, Matsuzaki O, Kupniewski D, Bard J, Thomas L and Boyse EA (1986) Influence of a genetic difference confined to mutation of $\mathrm{H}-2 \mathrm{k}$ on the incidence of pregnancy block in mice Proceedings National Academy of Sciences USA 83 740-741

Received 11 December 2002.

First decision 28 March 2003.

Revised manuscript received 25 April 2003.

Accepted 20 May 2003. 